\title{
A GAY WOMAN'S EXPERIENCES DURING HER CAREER IN THE DEPARTMENT OF DEFENCE: FLEET OF HOPE: A SOCIAL SCIENCE COMMENTARY - PART 2
}

\author{
BENEDICTOR LEAH TLOU \\ WILLEM SCHURINK \\ Programme in Leadership in Performance and Change \\ Department of Human Resource Management \\ Rand Afrikaans University
}

\begin{abstract}
This article is a follow-up on the autobiographical sketch, of a lesbian entitled: Fleet of Hope and offers social science comments on this "insider" account. After the South African Department of Defense's Policy on the Prevention and Elimination of Unfair Discrimination on the Grounds of Sexual Orientation have been outlined, and key theoretical concepts and views of scholars have been described briefly, an attempt is made to illuminate the gay woman's experiences including her former experiences of her career in the South African Department of Defense with the aid of these constructs. The article is concluded with some recommendations.
\end{abstract}

\section{OPSOMMING}

Hierdie artikel volg op die autobiografiese skets van 'n lesbiër, getiteld: Fleet of Hope, en bied sosiaal-wetenskaplike kommentaar op die "binnestaander" dokument. Nadat die Suid-Afrikaanse Departement van Verdediging se konsepbeleid oor die voorkoming en ïlluminering van onregverdige diskriminasie op grond van seksuele oriëntasie en belangrike teoretiese konsepte en opvattings van kundiges kortliks uiteengesit word, word gepoog om met hierdie konsepte die gay vrou se ervarings insluitende haar ervarings van haar eertydse loopbaan in die Suid-Afrikaanse Weermag te verklaar. Die artikel word met enkele aanbevelings afgesluit.

It is certainly no exaggeration to state that there has been changes in the rights of gays and lesbians in South Africa since 1990, when the liberation movements in the country was unbanned and the journey of the country's transition to democracy took off, that is almost inconceivable. Within at least gay circles, there has always been the belief that justice and true liberation in this country had to include a commitment to lesbian and gay equality. It is part of history that after much lobbing local gay activists managed to convinced the African National Council and that South Africa eventually become the first country to include sexual orientation as a protected class in its constitution in 1996 (cf. Klawitter, 2002; Gevisser $\&$ Cameron, 1994).

While gay liberation movements attended to many important issues there could be little doubt that two concerns that have been particularly important for gay activists are the right to samesex marriage or registered partnership (cf. Bell \& Binnie, 2002), and the right to fight for their country, or what has been referred to, as the gays in the military debate (Bell \& Binnie, 2002). This debate is upheld by some as having a destabilizing, radical function: opening up one of the most heteronormative state institutions to homosexuals begins the task of undermining heteronormativity itself (Bell \& Binne. 2002, p. 455).

Particularly striking is the fact that while South African gays' rights in its military institution are today constitutionally protected, this is not the case in two prominent Western democracies, namely the USA and the UK (cf. Bell \& Binnie, 2002). The determination to keep gays out of the armed forces, and/or to reinforce a system of official denial through sustained discharge of gay and lesbian military people (Richardson \& Seidman, 2002, p. 11), reveals the pervasiveness of national homophobia (Scott \& Stanley, 1994). It goes without saying that discrimination against gays in the military and its various departments sections, and regiments may have an affect on both gay employees and

Requests for copies should be addressed to: BL Tlou, Department of Human Resource Management, RAU University, PO Box 524, Auckland Park, 2006 heterosexual staff. Quite interesting is research findings concerning the "coming out" of gays and their ability to socialize with co-workers and to participate in the workplace community. Ellis and Riggle (1995), found that gays and lesbians who were "out" were more happy with their relationships with co-workers while those working for companies with anti-discrimination policies were more contented with their jobs. Schneider (1987) found that being "out" had not any direct effect on the chances of socializing with co-workers outside the office. Perhaps, the answer really lies, as (Klawitter, 2002, p. 332), proposes, in that the choice of strategy for "managing" sexual orientation determine the level of social integration: " $(\mathrm{t})$ hese strategies might minimize possible discrimination, but would also exact a toll by limiting social interaction at work" (Klawitter, 2002, p. 332).

Of paramount importance from human resource management and organizational perspectives, are, of course, managers' approaches, relationships, and interests in their gay employees and the extent they will engage them in the organization's strategic goals, and provide them with opportunities for skills training, and the effect of gay employees on the organization's culture, employee wellbeing, and organizational effectiveness, to mention but some important areas.

Anyone undertaking a literature study of lesbianism generally and female homosexuality in the military particularly, is bound to find that while the former has been studied for many decades by scholars from various disciplines and has resulted in a body of research and theorizing that has become extensive and specialized, much less scientific work, has been undertaken on the latter. Regarding South Africa, as far as could be established a limited number of studies on lesbianism are available (cf. Liddicoat, 1961; Muntingh, 1967; Redelinghuys, 1978; Schurink, 1979; Schurink, 1981, and Gevisser \& Cameron, 1994). Except for discussions of male homosexuality in the military (cf. Gevisser \& Cameron, 1994, and particularly Toms (1994), no local scientific work dealing with female homosexuality and the South African Defense Force could be found. 
AIM

In the light of the scarcity of local knowledge on lesbianism in the military and its possible effect on its functioning, this article strives to make a modest contribution in providing a basis for building knowledge on being both female and gay in the South African Defense Force.

We already pointed out, since the new South African government came to power in 1994, the rights of gay people in the Defense Force have been protected by the country's constitution. At this juncture, it is important that we get a clearer picture of what this really implies. In order to do this, we now review the South African Department of Defense's Policy on the Prevention and Elimination of Unfair Discrimination on the Grounds of Sexual Orientation.

\section{THE DRAFT POLICY ON THE PREVENTION AND ELIMINATION OF UNFAIR DISCRIMINATION ON THE GROUNDS OF SEXUAL ORIENTATION}

According to the Constitution of South Africa Act 108 of 1996, Section 9(3) states that the state may not unfairly discriminate directly or indirectly against anyone on one or more grounds including race, gender, sex, pregnancy, marital status, ethnic or social origin, colour, sexual orientation, age, disability, religion, conscience, belief, culture, language and birth. In the White Paper on Defense, the Department of Defense declared that it would operate within the parameters of the Constitution with respect to human rights and non-discrimination against personnel on the grounds of their sexual orientation.

The Department of Defense has since the formation of the new South African National Department of Defense (DOD) in 1994, ventured into a new dispensation where equality between persons and respect for the human dignity of all its employees are core values. Equality can be effected in various ways including constructing and implementing a charter of fundamental rights, subscribing to international conventions or by introducing specific legislation. Equality guarantees persons the right that they will not be discriminate against on the following grounds, including but not limited to one's race, gender, sex, pregnancy, marital status, ethnic or social origin, colour, sexual orientation, age, disability, religion, conscience, belief, culture, language, birth and social responsibility.

According to the DOD's draft policy on non-discrimination on grounds of sexual orientation, it does not judge sexual orientation in terms of right or wrong, nor does it make any value judgement in this regard, but accepts differences in sexual orientation as a given. The policy is necessary to combat discrimination in the organisation based on people's sexual orientation and the draft policy document stipulates that discrimination on the grounds of homophobia4 and or heterosexism, whether overt or covert is prohibited as well as its condoning by any person. Harassment on the grounds of sexual orientation will not be tolerated and mechanisms are to be established to deal with such incidences.

Special policy with regard to sexual orientation is deemed necessary since discrimination, specifically on the grounds of sexual orientation has been occurring quite extensively in the DOD. Changing the status quo calls for nothing less than a paradigm shift. DOD leaders are obliged not to ignore or condone unfair discrimination in any form, and need to take whatever action is required to ensure that a recipient of discrimination will not subsequently become a victim of reprisal or retaliation. These obligations are part of the broader responsibility of the Commanding Officer. In addition, managers have to foster a positive climate and have to take appropriate corrective action when conduct is disruptive, provocative, discriminatory, or otherwise unprofessional.
The respective norms and role prescriptions contained in the DOD's policy on unfair discrimination on the grounds of sexual orientation are:

- The DOD must comprise an optimally integrated group of men and women who must be able to work together to accomplish the Department's mission.

- All DOD personnel, military and civilian are entitled to be treated fairly with dignity and respect, and must be allowed to work in an environment free of unfair discrimination and other inappropriate behaviour.

- Unfair discrimination on the grounds of sexual orientation is prohibited.

- Since leadership is key to eliminate unfair discrimination it should be the cornerstone of any effort to eliminate such discrimination.

- Upon accession and annually, all DOD personnel will be educated/trained in the identification, prevention, resolution and elimination of unfair discrimination including sexual orientation.

- Individuals who believe they have been unfairly discriminated against on the grounds of sexual orientation will be afforded multiple avenues to seek resolution and redress; all personnel will be made aware of these avenues. Counseling support or referral services will be made available to all involved in incidents of unfair discrimination.

- The Officer Commanding and those in supervisory positions should ensure that complaints of unfair discrimination are made in a confidential climate that does not tolerate acts of reprisal, intimidation, or further acts of covert discrimination.

- All reported incidents of unfair discrimination based on sexual orientation would be promptly investigated and resolved at the lowest appropriate level in a dignified and sensitive way. Confidentiality will be maintained and appropriate feedback will be provided to the members or employees involved.

Before relating some social science concepts to Thando's views, rationalizations and everyday experiences of her life and her career in the South African Defence Force, as recorded in her sketch, we first need to apprehend these abstract theoretical concepts and scholarly views regarding homosexuality and the military.

\section{KEY THEORETICAL CONSTRUCTS AND SCHOLARLY VIEWS REGARDING HOMOSEXUALITY AND THE MILITARY}

According to Heinecken (1999) the term sexual orientation refers to the innate disposition of human beings to express their sexuality. Heterosexuality, homosexuality (lesbian women and gay men) and bisexuality are included in this definition. Within the military a distinction is made between homosexual orientation and homosexual conduct. According to Plummer (in Heinecken, 1999, p. 45) homosexual conduct can be classified according to the following four categories:

i) Casual homosexuality is a passing homosexual encounter that does not substantially structure the overall (sexual) life of the individual.

ii) Situational homosexuality refers to circumstances in which homosexual activities regularly occur, but where these do not become an individual's overriding preference once removed from the environment. This can be seen in settings such as prisons and military camps, where this type of sexual activity is seen as a mere substitute for heterosexual behaviour.

iii) Personalised homosexuality refers to individuals who have a preference for homosexual activities, but who keep their sexual preference a secret - hidden from friends and colleagues.

iv) Homosexuality as a way of life refers to individuals who openly acknowledge their sexual preference and for whom homosexual activity is integrated into a distinct lifestyle. 
Heinecken (1999) indicates that in the African context, situational same sex activities have been the more prevalent form of homosexuality whereas in Europe the tendency towards homosexuality as a lifestyle is greater.

In the past the former SADF Personnel Code clearly discriminated against the homosexuals. Former arguments were based on the impact of homosexual behaviour on military effectiveness. The SADF Personnel Code, Section E/V/XVI, classified homosexuality as sexually deviant and immoral behaviour. This meant that persons would not be selected as permanent force members if they indicated that they were gay. If there were any reasonable doubt about a person's sexual orientation, especially if the person was destined to be in the officer corp or an instructor, this would automatically lead to non-appointment (Heinecken, 1998).

Where a force member was found guilty of a homosexual act the person concerned was subject to disciplinary action and, pending the nature of or the gravity of the misconduct, the person would be discharged if found guilty during a court martial. At present, in South Africa, as already been indicated, current legislation does not discriminate against anyone based on sexual orientation and therefore a person's sexual preference is not questioned during recruiting. Positions are supposed to be allocated to those who can best do the job and to those who meet the requirements; sexual orientation is not considered to measure a person's capability in career opportunities.

\section{Homosexuals and the military}

According to Heinecken (1998) even though homosexual men and women are in principle fit for military service, many people still consider persons with a homosexual orientation to be less suited for duty in the military than heterosexuals. These arguments are based primarily on the effect of homosexual behaviour; such as that conduct may hamper the soldiers' discipline, morale and cohesion. These are similar to the concerns that led to the restrictions and sanctions applied to homosexuals in the then SADF.

A major concern is that homosexuals can be easily intimidated, blackmailed or manipulated by those who wish to expose their sexual identity. Consequently, homosexuals have been considered to be 'a national security risk' because of their susceptibility to blackmail or threat of exposure (Heinecken, 1998). It is said that because homosexuals are forced to conceal their sexual identity, they are more likely to manifest psychological disorders.

Heinecken (1999) stated that homosexuality is considered to be a mental disorder that renders a person unstable. Not only do homosexuals battle to cope with their sexual identity, but as a stigmatized group, they are placed under considerable pressure to manage potentially damaging information about themselves if they want to pursue a military career or avoid adverse reaction from the heterosexual majority. There is however, no scientific proof that homosexuals are mentally unstable than heterosexuals.

According to the U.S. News (1989) in classical Greece, homosexual bonds between soldiers were encouraged and considered an asset to a fighting army. This of course does not happen in modern times. For years the United States of America has maintained one of the toughest policies in the world, banning homosexuals from the military service. According to their Department of Defense records, about 1,700 officers and enlisted men and women are discharged each year for homosexuality, and many suffer because of such action. According to this policy, the presence of such members adversely affects the ability of the armed forces to maintain discipline, good order and morale.

\section{Homosexuality and military effectiveness}

As has already been indicated homosexuals are seen as unsuitable for military service because they pose a security risk and because their presence in the military disrupts group cohesion, morale and discipline. Heinecken (1999) stated that because of homophobic sentiments, gay soldiers are unable to function effectively in the military because the heterosexual majority does not want to socialize with them, and when in position of command, they often fail to demand the respect of their subordinates. All these negative situations evolve around one central assumption namely: acceptance of homosexuals in the military will undermine military effectiveness.

Most of the preceding arguments are based on prejudice against homosexuals of which there has not been any poof that their integration into the military has undermined operational effectiveness. There is also no scientific evidence indicating that homosexual people are inherently less capable of military service than heterosexual men and women. Furthermore, no explanation as to why discrimination on the basis of sexual orientation is necessary to preserve the good order, discipline and morale has been offered.

Heinecken (1999) stated that the few studies that exist indicate that both gays and lesbians are loyal; they accept the surrounding heterosexual culture, comply with the physical and emotional demands of their job, are not security risks and conduct themselves in a professional manner. She further contends that, gays' exclusion is based on the professional military judgment of the "possible" effect same gender people may have on military effectiveness and not on scientific evidence.

According to the Washington Post (1991) Greg Greely, the Air force Captain whose discharge was held up after he carried a banner in the Lesbian and Gay Pride Parade in Washington has been released with an honorable discharge. Greely worked with computer systems in the Pentagon, he had not previously announced that he is gay and was questioned, because he had a security clearance for classified information and because they thought someone could use knowledge of him being gay against him. In response to Greely's discharge Rep. Joseph P. Kennedy, said in a speech that the Pentagon was using "Stone Age" thinking, because there has never been any evidence that Capt. Greely was ever less than courageous or served his country less than admirably. He further stated that the fact that he is gay does not change that.

Bell and Binnie (2002) point out that the gays in the military debate in the USA can be seen to promote passing as the only possible strategy for homosexuals serving in the military, since any form of homosexual conduct including coming out as an "admitted homosexual" contravenes the Defense Department's policy. In fact, "(e)ven withholding homosexual identity - by passing - can, however, be used as grounds for dismissal ..." (Bell \& Binnie, 2002, p. 453). Stychin, 1995, p. 94) provides the following example:

"Steffan was under a positive duty as a member of the military to come out because his gay identity was otherwise undetectable but contrary to regulations. The result of his coming out, though, was his expulsion as unfit for the service. Paradoxically, however, in going public he revealed that his sexuality had not rendered him capable of service. He demonstrated, instead, that absent a public declaration, he remained completely undetectable on the inside of what is, in the end, an institution forged with same-sex bonds.

As Bell and Binnie (2002) point out Steffan's presence in the navy threatened to destabilize the distinction between sanctioned "homosociality" and an outlawed homosexuality, a distinction in reality dangerously supported in institutions like the military. "The navy's fear, put simply, is of contagion (backed 
up arguments upholding Steffan's expulsion centred on the 'thread' of HIV and AIDS impacting on the 'healthy' military's ability to defend the nation) (Bell and Binnie (2002, p. 454). Stychin (1995, p. 99) describes this state of affairs:

"Joseph Steffan was defined as an outsider because of his ability to pass - to reveal, through the articulation of a gay identity, that he was an insider all along. However, in assimilating the military with the nation, Steffan is further constructed, not as being an insider but as performing the role of the insider - as an espionage agent might perform a role to undermine national security. The underlying concern, then, is not simply that Steffan had successfully performed the role until his own revelation, but that his success had revealed the performativity of the military subject.'

\section{The issue of privacy}

From the literature available on gays in the military it is clear that a "complex intertwining of privacy, equality and expression central to current forms of sexual citizenship agitation (and to its regulation)" exists (Bell \& Binnie, 2002, p. 453). Hunter (1995, p. 139) puts this as follows:

"The ban on military service by lesbians, gay men, and bisexuals...renders identical conduct such as kissing permissible or punishable based on the sexual orientation of the actor. Moreover, the ban restricts self-identifying speech with the justification that homosexual 'conduct' is antithetical to morale, good order and discipline."

The prejudices with regard to the issue of privacy have also been explained by the fact that heterosexuals do not want to share mess facilities or living quarters with those of the same sex, who may find them sexually attractive. According to Heinecken (1999) this is based on the notion that homosexuals will not be able to control their sexual impulses and will therefore harass and invade the privacy of fellow soldiers. The military's concern over privacy rests on the stereotype that homosexuals are superficials who will exploit their positions of authority to sexually harass their subordinates. There is however, no evidence to support the notion that lesbians and gay men are more likely than heterosexuals to engage in sexual harassment or are less able to control their sexual impulses than their "straight" counterparts (Heinecken, 1999). This brief discussion of some key views found in the literature on homosexuality and homosexuality will suffice.

\section{A SOCIAL SCIENCE COMMENTARY}

In the remainder of the article, concepts and views from scientists briefly referred to in the preceding paragraphs as well as other key existing theoretical constructs will be compared and in a sense "tested" by establishing to what degree such second order constructs accommodates Thando's views, rationalizations and everyday experiences as recorded in her sketch. The approach used by Lowney, and the Winslows (1981) and Schurink (1979, 1981, 1989 \& 2002) will generally be followed here.

The relevancy of general theoretical constructs of homosexuality and lesbianism

Thando comes from a normal well-adjusted home life, filled with love and humour, hope and expectations; playing cowboys and Indians, going on holidays with her family and enjoying the benefits of a strong family unit. This is contrary to what Simon and Gagnon (1973) found in their study namely that their respondents generally came from broken homes and that the majority preferred one parent to the other. Thando is from a stable family except that her elder sister Grace - who also acted as her surrogate mother - was gay and she was shunned by the family and always made to feel unwelcome. In Schurink (1981) less than half of the cases come from broken homes. In relation to another study by Schurink (1979), it appears that the respondent comes from a home where the parents were divorced, and although this was traumatic for her she indicated that it did not contribute to her homosexuality.

According to Simon and Gagnon (1973), lesbians are unable to enter into conventional heterosexual relationships even during their school years. Thando did not experience this because she had her first boyfriend at the age of 14 years and more boyfriends followed: At the age of 19, I entered into my first serious relationship with a man. We were both students and thought we had the world at our feet. It lasted 2 years. In Schurink (1981) the majority of the lesbians became aware of their homosexuality only in late adolescence or early adulthood. According to Schurink (1979) Wendy did not experience the problem because she had a normal amount of boyfriends as a girl.

Plummer (1992) indicates that coming out is a central feature of the experience of lesbians and gay men in the western world, but that there remains much disagreements about what coming out means, how it happens and what drives the process forward. There is however a general agreement that coming out begins with an individual who is either unaware of her/his sexual orientation or shares the general view that to be homosexual is to be degraded, denounced, devalued or treated as different, and ends with a person relatively happy with her/his sexuality, acknowledging this to the self and to others. In relation to Thando's experience of coming out the following excerpt is relevant:

I actively participated in anti - homosexual discussion and debates. Voicing my opinion to anyone who cared to listen. I was the typical 'verbal gay basher'. It was a time of constant questioning of my new lifestyle and myself and trying to justify why I had made the move. I believe today that the reason I was so radically anti-gay was my way of trying to convince myself that I was not 'made up of the same stuff' as Grace. It was also a time of great anxiety that someone would find out about me and inform my parents. It was a long road of self discovery sometimes filled with self doubt, guilt and anxiety but it was a road that led to my current lifestyle.

Cain (1991) confirms this type of behaviour where he states that gay men and lesbian women engage in a lifelong process of information management concerning their sexual preferences and identity. According to him this happens because gays are already aware of the potential for stigmatisation by the time they begin to define themselves as homosexual or at least potentially homosexual.

In contrast to the popular belief that, lesbianism originates as a result of the seduction by an older woman Thando was never seduced by any woman and never had any sexual relation with another woman until she met a girl who worked with her and was openly gay.

The unthinkable happened at 22. I met a girl working with me. Openly gay, she stood for everything I abhorred. I verbally attacked her and took any opportunity to insult her lover and friends. Despite the insults, she became a friend. The irony of the situation was that I wanted to be in her company all the time. She resigned (from the Defence Force) and left for Durban. I followed because I was starting to realise that perhaps I wanted to be more than just a friend. I believed she had to be aware of my growing feelings for her yet she never made any advances and I was becoming increasingly frustrated and confused. I was terrified but finally I made the bold move to tell her I was sexually attracted to her".

This is also denied in Schurink's (1981) study where it is indicated that in general entry into homosexual way of life was not a result of seduction by an older woman. According to Wendy (Schurink, 1979) she was not seduced and had no sexual relations with another woman before she met her lover, Marie. 
Although the butch and femme roles are generally accepted by both the homosexual and heterosexual culture, Thando and her partner do not admit to these roles as part of their homosexual way of life: Traditional gay roles were never established. We were equal partners drawing strengths from each other. Both worked in the garden, both did the cooking and both cleaned the house amongst other shared duties. In Schurink (1981) study, although the butch-femme dichotomy was significant for some of the lesbians at one time or another, it appears that they prefer the women with whom they enter into affairs with, to act in a feminine and not masculine way towards them. In Schurink (1979) Wendy in her sketch refers to the butch and femme dichotomy in the lesbian way of life at intervals.

According to Simon and Gagnon (1973) attendance and/or membership of homosexual clubs or bars predominantly frequented by lesbians can contribute to homosexuality. It seems that this is not the case with Thando because such places were for support and served to strengthen a sense of belonging to the gay culture. As she indicated:

Cape Town was a hive of active lesbianism with lesbian gatherings at pre-arranged clubs where everybody brought their own alcohol and eats, also known as "gatparties", strong bonds and many relationships formed and broken within the group. Just being in the company of other swans made the idea of "being different" so much easier to accept. The strangest part of the whole subculture we lived in was that very few relationships were pursued with straight swans. It was an unwritten rule that the gay swans would not actively seek out and try and convert straight swans. Perhaps this was due, in part, to fear of military 'justice'.

According to Schurink (1979) Wendy also indicated that such meeting places are of importance to lesbians since they are places where they can relax and enjoy themselves without getting into trouble with heterosexual people.

Like the majority of Simon and Gagnon's (1973) subjects, it appears as if Thando has maintained contact with all her family members. This is also confirmed in Schurink's study (1981) where he indicated that lesbians, with one single exception, maintain contact with their family members and there is usually at least one in the family who accepts their sexual orientation. This can also be seen in Schurink (1979) where Wendy maintained contact with her mother and the fact that she was homosexual did not bother her. Thando writes:

In the 90's we settled down as a married couple would. We both felt very comfortable with the fact that we were lesbians, that we had made a commitment to each other and we both found that everybody around us seemed more relaxed and accepting of our lifestyle. My parents were invited and they became regular visitors. I had always had a close relationship with them but had just kept my own private life very much apart from my family life. They never mentioned the fact that I was gay but it was evident that they were aware that I was happy. They had a good relationship with Sarah (my lover) and they had softened their stance considerably towards my sister Grace. After the death of both my parents and four years down the line I still have not discussed the matter with my other siblings even though they are all aware of my sexual orientation. My sister Daisy is totally homophobic and if the subject is brought up she either ignores the issue or derides it. That is the way she feels and I respect her opinion on it. My brother John is more relaxed and even though we have never openly spoken about my being gay, we will discuss homosexual issues and my homosexual friends in a very open manner. They all have their own married lives and families to contend with as well, so it is not as though my sexual orientation is a 'top of mind' issue with them.

It can be stated that Simon and Gagnon's (1973) hypothesis that lesbians are largely dependent does not seem to be valid in
Thando's case. This is because Thando has always been independent and she started working part-time at the age of 21. She had a career of more than 10 years in the Department of Defence and she is currently in a stable and fulfilling job in a media marketing company: I am happy, I have a great partner, I own a beautiful home and have a circle of friends and a family who love me for who I am. What more do I need? In Schurink (1981) the overwhelming majority of the homosexual women attaches a great deal of importance to their work and generally enjoy it. This is also reflected in Schurink (1979) where it is indicated that work is important for Wendy, even if her work record cannot be regarded to be stable, she however, finds work to be rewarding and attractive as she hates being idle.

In contrast to what Simon and Gagnon (1973) have hypothesised, Thando does not seem to use "a great love" to neutralize any feelings of guilt her lesbian way of life may have caused her:

It was a long road of self discovery sometimes filled with self doubt, guilt and anxiety but it was a road that led to my current lifestyle. I am involved with a great woman who loves and cares for me as a person of the world capable of leading nations, if perhaps not Naval troops. Looking back at my life, I suppose, as with all people, there are things I would have wanted to be different, things I would have done differently. Perhaps I should have joined the Army or SAMS? Perhaps I should have taken the Officer selection issue further. I didn't and that is that. However, the most important thing I have learnt, is that we have so much to be thankful for and so much that we can still do that there is no time to be wasted on regrets.

This is also reflected in Schurink's study (1981) where it is indicated that love plays a very important role in the lives of the women and seems that all of them have to a greater or lesser extent established love relationships with other women. Simon and Gagnon's (1973) hypothesis is also not applicable in Wendy's autobiography (Schurink, 1979).

Although there was a time in Thando's life where she seemed confused and doubtful about being gay, she seems to have come to terms with her condition and adjusted quite well:

It was a time of constant questioning of myself and my new lifestyle and trying to justify why I had made the move. I believe today that the reason I was so radically anti-gay was my way of trying to convince myself that I was not 'made up of the same stuff' as Grace. I couldn't come to terms with the idea that I was gay and on various occasions set out to prove to myself and anybody who cared to listen that I was attractive to men as well as attracted to them.

According to Plummer (1975) some scholars have commented that homosexuality is increasingly becoming a life style rather than an individual condition, that is, individuals experiencing this form of homosexuality have defined themselves as homosexuals; have made it a central part of their lifestyle; have developed fairly stable patterns of interactions with other self-defined homosexuals; and have fostered their own series of beliefs, values and perspectives on homosexuality. In many ways, this could be called a homosexual subculture. According to Schurink (1981) it is mentioned that although the women did experience up to a certain extent some problems with respect to aspects of this lifestyle, as a group they appear to have made reasonably good adjustments to this way of life as a whole.

According to Diamant (1993) several studies of prejudice against gay, lesbian and bisexual people suggest that intergroup contact may reduce prejudice based on sexual orientation. Exposure to information about gay, lesbian and bisexual people often leads to a reduction in anti-gay prejudice. Similarly, people who know someone who is openly gay have more favourable attitudes towards gay people than people who do 
not. Another study suggests that contact not only lessens heterosexual's negative attitudes towards gay men and lesbians, but also significantly improves the ability of heterosexuals to work effectively with gays. This is evident in the following part of Thando's sketch:

I was offered a job at a media marketing company and suddenly found myself being faced with a life where I didn't have to hide my sexual orientation, lie about my partner or fear reprisals from my superiors. I did at first, because I didn't feel comfortable speaking about it. I wasn't sure what the response would be and I definitely didn't know what would happen if they discovered my secret. To my great astonishment, when I finally made the disclosure it was met with blank stares of "so what?" It was almost more difficult to disclose it to people who didn't find it scary, compromising or even threatening. How could they be so okay with it when I had been led to believe for more than a decade that it was not acceptable? What made people in the Navy so narrow minded compared to civilians? The obvious deduction is that they are exposed to so much more, but I also believe it has to do with the environments we find ourselves in.

Diamant (1993) indicates that one important factor that influences the effect of contact or attitudes is "institutional support", or the attitudes of those in authority towards the stigmatized group and discrimination against them. If the military chooses to oppose prejudice, prejudice will recede; if the military continues to endorse prejudice through the exclusionary policy, prejudice will continue. This clearly confirms what Thando had to endure, that is, being refused in the officer corp just on the basis that an Admiral had asked a colleague if she would be able to work with someone who is a lesbian and she responded negatively. It highlighted the predicament many straight people have been confronted with, in the Defense Force, if not the entire world. Thando recalled:

Once they knew you, they could deal with the sexual direction you took but they were never completely at ease with it and found it easier to look the other way when backing was required. This has nothing to do with the fact that you are a lesbian. It is a human phenomenon that people are not that eager to stand up and fight or in this case, stand up and defend. When they have to defend something that is not totally familiar to them it is easier to back off and let you face your problems alone.

The relevancy of scholarly views on homosexuality and lesbianism in the armed forces

According to Heinecken (1999) in South Africa, the situation exists where homosexuality is permitted by the law, rather than accepted. A decrease in hostile attitudes is not the same as an increase in social acceptance. What may at first glance appear, as an increase in liberal attitudes is actually a mere growth in indifference. This is true in relation to Thando's experiences:

(T)he feeling of insecurity within the military felt by all gay members wascalways present. The introduction of young lesbian swans changed the mood somewhat. They never felt the force of homophobia within the Defense Force and were quite happy and proud to show their sexual orientation. That seeped through the system and by the time I left, the overall mood was not fear, even though the older guard was still cautious.

Anderson and Smith (1993) provide research findings on the actual experience of serving in the military in their study with interviewees who are veterans and active duty personnel in the US military. Most of the interviewees indicated that their military experience was very positive, except for the homophobia they encountered and their own fear of being identified and punished by the military. Some indicated they grew a lot personally through their military experience, gained self-respect, and some even indicated that they grew from the negative experiences. Others indicated that being in the military helped them to form positive image of themselves - an image of gay and lesbian people doing well even in a homophobic system. On the other hand other interviewees indicated that the military experience is not positive for many gay people because of the direct experience of homophobia, isolation, keeping separate, not being able to share, and lying.

Retief (1993), a South African commentator, states that one prejudiced myth about lesbian and gay people is that since sexual contact does not produce offspring, they must reproduce themselves by corrupting the young into their gay sexual ways. Thando denies the existence of this prejudiced myth:

The strangest part of the whole subculture we lived in was that very few relationships were pursued with straight swans. It was an unwritten rule that the gay swans would not actively seek out and try and convert straight swans. Perhaps this was due, in part, to fear of military "justice".

And further:

I applied for and was accepted as a Navy recruit and went to Basics feeling more secure than I had in a long time. I felt part of a community and I immediately made friends with a fellow recruit who was gay and who knew many of the, then, current gay females in the Navy called Swans. Entering a New World where drills, shining of boots, also known as 'boning' and sunset had new meaning. It also brought new meaning to the word homosexuality, discrimination and frustration. I was once again placed in a world where the mere mention of the word homosexuality was frowned on. However, this time it was not on an emotional footing as with my parents and siblings. This time it was deemed dirty, portrayed as evil and definitely not correct. For the first time in my life, I was mixing, not with just a partner but a whole group of lesbians, yet, I was feeling even more isolated because of the barriers, reservations and limitations from a homophobic military discipline. We were forced to be careful, forced to be underhand and forced to be heterosexual.

And finally:

Back home, I was pressurized into making appropriate career decisions and found myself looking at a picture of a female in uniform, graced with beauty, intelligence and style. This coupled to the general perception that many women in uniform were believed to be gay convinced me that I wanted to join the Defense Force. Still not sure of my sexuality I was not interested in joining the Army, perceiving the women to be 'butch' and 'undesirable' in the social context. Whatever I was and whatever I was going to be, 'butch' was not an option. I had no intention of loosing my femininity, dressing up in check shirts, big buckles, men's boots and men's pants. I still wanted to believe that I could be desirable to men and even if I was boyish and lived in jeans, that did not mean looking like a man. I believed a 'butch' to be the stereotype with no make-up, shortcropped hair, large and masculine.

According to Diamant (1993), the study undertaken by Anderson and Smith reflects that gay, lesbian and bisexual people join the military because they are highly supportive of it and hold strong patriotic beliefs, notwithstanding their opposition to its policy on homosexuality.

Anderson and Smith (1993) point out that the effects of being identified investigated and discharged is clearly negative. An allegation of being homosexual, regardless of any proof can result in revocation of a security clearance or the end of a career. Thando reveals:

Security clearances were forever bandied about as the 'gateway to heaven'. If you had a confidential clearance you qualified for promotion. The first question was always 'are you a lesbian and do you have lesbian friends' - Non committal answers were always sought, even to the point were you would rehearse the question with friends over and over again to answer in the 
appropriate manner when the dreaded question was flung your way. This was common practice. If you didn't get your clearance you were placed in a dead end job with no chance of promotion. This happened to many lesbians in the Navy. I was fortunate. I was granted a confidential clearance, valid for ten years, first time around. Being young and ambitious I was pretty sure at the time that I would not even last ten years in the Navy and would therefore never have to undergo another inquisition. I felt that there might be better opportunities in the civilian world but I didn't want to enter that world at that time.

According to Heinecken (1999) one of the main arguments against the admittance of homosexuals in the military is that they pose a security risk, because they are forced to conceal their sexual identity, and therefore homosexual are likely to manifest psychological disorders, are more susceptible to blackmail, are less trustworthy and respectful of rules and laws. This is evident in Thando's sketch where she and the others had to keep their sexual orientation a secret for fear of victimization, but there is no indication that reflects that Thando had manifested psychological disorders as a result of concealing her sexual identity. Thando writes:

I was once again placed in a world where the mere mention of the word homosexuality was frowned on. However, this time it was not on an emotional footing as with my parents and siblings. This time it was deemed dirty, portrayed as evil and definitely not correct. For the first time in my life, I was mixing, not with just a partner but a whole group of lesbians, yet, I was feeling even more isolated because of the barriers, reservations and limitations from a homophobic military discipline.

Although many homosexuals have served honourably in the military, and still do, few reveal their sexual identity because to succeed in the military environment, most feel pressured to hide their sexual orientation and this is precisely the predicament that places homosexuals in the armed forces in a double bind (Heinecken, 1999). This is clearly portrayed by Thando where she states:

The majority of these 'bad element swans' were junior ratings, even though some had been in the Navy for many years, but for some or other reason had always been overlooked for promotion. A small number of swans were promoted to senior rating ranks but were placed in posts that didn't have much future.

Even though the draft policy on prevention and elimination of unfair discrimination on the grounds of sexual orientation explicitly forbid discrimination on the grounds of sexual orientation, gays and lesbians in the DOD have remained in the closet and the issue of homosexuality within the ranks remains mute. This is because of fear of victimization and career stagnation. Since Thando had concealed her sexual orientation and was in the closet at some stage in her career, she mentions: Accelerated promotions followed, due to the belief of my immediate superiors that I was a good candidate for future success.

The draft policy on the prevention and elimination of unfair discrimination on the grounds of sexual orientation stipulates that leadership has a crucial role to play in eliminating all forms of unfair discrimination, fostering a positive climate and disseminating clear command policy, as well as creating and nurturing the processes to implement and maintain it. That is, leadership is a key to eliminating unfair discrimination and must be the cornerstone of the effort to eliminate such. In relation to Thando's sketch this aspect was contravened, in the sense that a person in higher authority who was supposed to protect her against unfair discrimination was the perpetrator in this case. The DOD lost an asset as a result of lack of commitment to legislation.

The policy also stipulates that every member in the DOD is entitled to work in an environment free from all forms of unfair discrimination. Thando and her gay colleagues were forced by the circumstances and fear of victimization to conceal their sexual orientation. Thando relates:

The personal life of a lesbian swan was far removed from the military day-to-day activities. Veiled threats, verbal cautions and of course the endless psychological battering of those who were different were apparent right from the start. The irony of the whole situation was that many of these women throwing stones, were themselves deemed 'possible undesirables' but due to a fear of the system, a fear of victimisation and a fear of ending up in a dead end job, they attacked with everything they had.

According to Anderson and Smith (1993) the great majority of gay, lesbian and bisexual people adjust to the stigma, prejudice, and discrimination associated with their sexual orientation. Studies demonstrate that these people are psychologically well adjusted, and that only a small group who fails to do so is troubled and dysfunctional. In respect of Thando's case she seems to have been capable of rising up and believing in herself more especially after leaving the defense force:

By this time, my self-esteem had taken a battering and I was questioning my qualities as a leader. How could I be a good leader if I am gay? My self-image had been dented more than I had thought. I was not this female/male freak who corrupted girls. I was a wholly desirable female, educated, passionate about my country and the peoples within it and with every right to hold my head up high in society. I was very fortunate that the company I worked for believed in 'humankind', specializing in cultural diversity. This placed me in a unique situation, where the colleagues I worked with were open and unbiased to all races, sexual orientation and religions.

Heinecken (1999) indicates that the few studies that exist indicate that both gays and lesbians are loyal; they accept the surrounding heterosexual culture, comply with the physical and emotional demands of their job, are not a security risk and conduct themselves in a professional manner. This can clearly be depicted in Thando's story where she points out that:

Selection was on and once again I came out with top honours. Requirements for passing were standard psychological testing, fitness tests; work related situational exams and panel discussions as well as teamwork and general observations. After discussions with my Candidate Assessment Superior (the divisional officer of the candidates), instructors as well as discussions with the psychologists I was told that I was doing far better than what was required and acceptance was but a formality.

Heinecken (1999) states that because of homophobic sentiments, gay soldiers are unable to function effectively in the military because the heterosexual majority does not want to socialize with them, and when in position of command, they will fail to demand the respect of their subordinates. All these evolve around one central issue namely: acceptance of homosexuals in the military will undermine military effectiveness. This clearly confirms Thando's experiences. Where she was victimized, she was not allowed to be an officer just from merely questioning one of the candidates. This is how she puts it:

During this time, an admiral received the written signal and decided to do a bit of impromptu investigation. Approaching a colleague, she was asked in a vague manner whether she would respond to a gay officer giving her orders. She replied in the negative. Need I say more? I was at no time questioned by this man yet he decided on the basis of one reply that I was not officer material. The signal that was officially released had my name inserted one line lower than the original. One line lower meant NOT ACCEPTED. At no time was any mention made as to the reasons for the non-acceptance. In fact at no stage was a letter of refusal even forwarded to me. When I questioned the Officer in 
charge of selection he made a vague reference to the fact that no posts were available, but shortly after that 2 appointments were made in exactly the posts that I had requested. After confronting the female colleague she confirmed the question but also commented that she would have had no problem receiving orders from a lesbian especially if she had known it was I. It is a fact that people base their perceptions on stereotypes and only after getting past the wall of bias can you start showing who you truly are and what you are capable of. In the case of lesbians you have not only the disadvantage of being a woman in a male dominated environment but also the added disadvantage of being a lesbian.

The military's concern over privacy rests on the stereotype that homosexuals are "superficials" who will exploit their positions of authority to sexually harass their subordinates. There is however, no evidence to support the notion that lesbians and gay men are more likely than heterosexuals to engage in sexual harassment or are less able to control their sexual impulses than their "straight" counterparts (Heinecken, 1999). This is reflected in Thando's account, where she made mention of the fact:

Even though by far the majority of lesbians in the Defense Force had stable, mature and long relationships, this did not matter. The feeling was that you could flirt, seduce, fraternize and break marriages, as long as you were 'NORMAL'. A straight woman could sleep around as much as she liked, but still be more highly regarded than a lesbian. As I mentioned earlier, we were judged by our sexual orientation more than by our capabilities and that was infuriating. To this day I still cannot understand the double standards.

According to Gevisser and Cameron (1994) the overbearing emphasis on heterosexual familial relations had great influence on social attitudes in the barracks, and this is compounded by the official censure of homosexual activity. Homophobia is encouraged in the barracks. This is clearly reflected by Thando where she writes:

I was once again placed in a world where the mere mention of the word homosexuality was frowned on. Upon arriving in this brave new world of sailors, we were introduced to the 'rights' and the 'wrongs' of military life. This included, much to my surprise, an immediate and serious discussion regarding the bad elements in the SA Navy. They were described as dangerous and manipulative - living unhealthy lifestyles - also described as only wanting to corrupt new recruits.

This is also emphasized in the study conducted by Retief (1993) on police actions towards gay and bisexual men in South Africa. He indicated that historically, government policy in South Africa has been aimed at curbing homosexuality so as to preserve the "moral fiber" of the South African nation.

Although not every gay person in the military is arrested, tried, insulted and assaulted, there is an ever-present threat that is constructed by the rank. It is an open discouragement of any form of queer behaviour, and since mere discouragement is never enough to do away with normal impulses, a form of hidden terrorism against gays prevails which permeates every echelon of the military environment (Gevisser \& Cameron, 1994). This relates to Thando's story where she was victimised and sidelined for officership irrespective of her excellent performance and the fact that she was way above the test requirements for her to qualify to be an officer.

This situation still prevails today where homosexuality is permitted by the law, rather than socially accepted. Although there is a decrease in visible hostile attitudes in the military, there is however no indication in an increase in social acceptance (Heinecken, 1999). This relates to Thando's experience:

However, the feeling of insecurity within the military felt by all gay members was always present. The introduction of young lesbian swans changed the mood somewhat. They never felt the force of homophobia within the Defense Force and were quite happy and proud to show their sexual orientation. That seeped through the system and by the time I left, the overall mood was not fear, even though the older guard was still cautious. Today the word is much less threatening and acceptable but in the 80's it conjured up images of 'total social outcast'.

\section{CONCLUSION AND RECOMMENDATIONS}

As is evident in Thando's sketch, valuable and rich information were obtained on South African female homosexuality in general and lesbianism in the South African military context specifically. It is also clear that while a number of views of scholars and local policy makers are in accordance with Thando's views others don't seem to be useful.

It is important to note that even though in the national legislation, discrimination based on sexual orientation is prohibited; as reflected in both the White Paper on Defense and the Draft Policy on the Prevention and Elimination of Unfair Discrimination on the grounds of Sexual Orientation, negative attitudes towards homosexuals in the local military context are still prevalent. While visible hostile actions and attitudes against homosexuals may have decreased, there is clearly a lack of social acceptance in both the military and South African society at large. This requires first and foremost a more reinforced awareness campaign in the form of training so as to sensitize members of the DOD on the issue of homosexuality in the military and also about the general guidelines of the draft policy.

It is clear from an electronic literature search that the scientific studies undertaken in respect of homosexuality issues in the military and especially in the South African Defense Force is scarce. This absence of local knowledge points to a need to expand information regarding to gays and lesbians in the local military context, with a view of inculcating positive perceptions by enlightening the general public about the lesbianism issue in South Africa and specifically in the local military context.

It is a well-recognized fact amongst scholars that lesbians to a certain extent share the position of all women in society: their social status is globally, notwithstanding culturally and geographically differences, generally inferior to that of men. Wilton (1995, p. 184) writes aptly:

"There are important local differences in the symbolic, material, organizational and political structures of patriarchal power, but such structures weigh on women around the planet. Relative to men, women are kept poor, unhealthy, uneducated and powerless, and lesbians share in that general disadvantages.

Although sexuality and sexual identity are differently shaped and differently experienced within disparate (and sometimes incomparable) cultural, social and geographical locations, homosexuality exists worldwide and is subject to a variety of social, legal and physical restraints and punishments... Lesbians share in some sense the social position 'homosexual' with gay men, though their positioning is modulated by the interventions of gender and, in particular, of male power and male economic advantage".

She (Wilson, 1995, p. 189-190) continues:

"(Lesbians) share with non-lesbian women the problematic relationship to the labour market which has grown out of assumptions about women's domestic role. The end result is a chronic lack of educational and training opportunities, a lower average wage than men, poorer working conditions, an increased likelihood of ending up in part-time, low-status and insecure work, confinement to stereotypically 'feminine' sectors of the labour market and restricted promotion prospects". 
While one might argue that the many recent "gender" orientated initiatives taken to improve the position of women in society generally, and in the work sector specifically, have improved present-day women's social status, one cannot deny that in many cultures and geographical areas around the world the fairer sex's position at present still left much to be desired. Regarding lesbians, while we have little information at our disposal, many scholars working in the field of "lesbian sociology" would agree that those living a female homosexual lifestyle, have been, exploited and stigmatized in all key areas of social living. With regard to lesbians and the military, Wilton's (1995) remarks that citizenship is assumed to be male and a soldier, whose duty it is to fight and die for his nation when requested would probably and effectively excluding females from the military would be still be supported by many people around the globe today.

From organizational and human resource perspectives it is important to undertake systematic research on areas of human living generally, and the working sphere including the armed forces specifically. Such research is urgently required to study the perceived gravity of the situation faced by homosexually oriented workers, to examine the evolution of attitudes towards homosexuality and to make recommendations regarding present-day career implications. Gevisser and Cameron (1994) indicating that local homosexual experience is unique because of the history of division and resistance in South Africa, implicitly suggest further gay and male homosexual research in the country. It seems that a research agenda for local lesbian studies should enlighten us on the multifaceted world of South African lesbians and should at least for the immediate future provide guidelines to at least address the following: (i) discrimination against lesbians in employment and dismissal, (ii) homophobia as it affects both lesbians and South African society, (iii) the effects of exploitation, discrimination, and victimization on lesbian workers, and (iv) the role of social services and counseling in coping with these problems.

Although the present study provided some initial insights into the world of one concrete white lesbian who served her country for some years, in the light of the scarcity of scientific knowledge about homosexual issues in the South African military context, more research needs to be launched into the lives and experiences of both gay women and men in the DOD. More particularly, more knowledge is necessary in order to establish a scientific basis for the "examination" of the current Draft Policy on the Prevention and Elimination of Unfair Discrimination based on Sexual Orientation. Since homosexuality in occupational contexts including the Defense Force has obvious implications for the optimal organizational functioning of such governmental institutions and for developing effective human resources within them, it is equally important that more local research (qualitative and quantitative) should be conducted on homosexuality and organizational dimensions specifically. Such research should inter alia promote and sensitize the general public about gay and lesbian issues in an occupational context, and indicate the importance of non-discrimination on the grounds of sexual orientation. In short, issues related to lesbianism and male homosexuality needs to be highlighted as much as issues of race and gender in the workplace.

There seems to be a strong local feeling that steps need to be taken that would ensure as far as possible the prohibition of discriminatory actions against homosexual people in the South African Defense Force. Even though the draft policy stipulates that the DOD is committed to eliminate all forms of unfair discrimination to any of its employees/members on the grounds of sexual orientation, there is an urgent need to practically enforce this policy based on solid social science research. Here a participatory research design seems to be particularly relevant, i.e. a project should be designed, executed and evaluated by scholars and everyone involved and concerned with the DOD.

\section{REFERENCES}

Anderson, C.W. \& Smith, H.R. 1993. Stigma and honour: Gay, lesbian and bisexual people in the US military. In: Diamant, L. (Ed.). Homosexual issues in the workplace. USA: Taylor \& Francis.

Cain, R. 1991. Stigma management and gay identity development. Journal of the National Association of Social Workers. 36 (1): 67-73.

Constitution of the Republic of South Africa Act 108. 1996. Pretoria. Government Printers.

Diamant, L. 1993. Homosexual issues in the workplace. USA: Taylor \& Francis.

Draft Policy on non-discrimination on the grounds of sexual orientation in the Department of Defence. 2001.

Halley, J. 1999. Don't: a reader's guide to the military's anti-gay policy. London: Duke University Press.

Herek, G. et al. (Eds.). 1996. Out in the force: sexual orientation and the military. Chicago: University of Chicago Press.

Gevisser, M. \& Cameron, E. (Eds.). 1994. Defiant Desire: Gay and lesbian lives in South Africa. Braamfontein: Ravan Press.

Guba, E.G. \& Lincoln, Y.S. 1989. Fourth generation evaluation. Newbury Park, CA: Sage.

Goode, E.1984. Deviant behaviour. $2^{\text {nd }}$ ed. Englewood Cliffs, NJ: Prentice-Hall.

Heinecken, L. 1998. Social equality versus combat effectiveness: An institutional challenge for the military. African Security Review. 7 (6): 3-15.

Heinecken, L. 1999. The silent right: Homosexuality and the military. African Security Review. 8 (5): 43-55.

Hunter, N.D. 1995. Identity, speech and equality. In: Duggan, L. \& Hunter, D. (Eds.). Sex wars: sexual dissent and political culture. New York, Routledge. Pp. 123-141.

Klawitter, M.M. 2002. Gays and lesbians as workers and consumers in the economy. In: Richardson, D. \& Seidman, S. (Eds.). Handbook of lesbian and gay studies. Thousand Oaks, CA: Sage. Pp. 329-338.

Kritzinger, C. 1987. The social construction of lesbianism. London: Sage Publications.

Liddicoat, R. 1961. A study of non-institutionalised homosexuals. Journal of National Institute of Personnel Research. NIPR 8: 217-249.

Lowney, J. Winslow, R.W. \& Winslow, V. 1981. Deviant reality. Alternative world views. Second Edition. Boston: Allyn \& Bacon, Inc.

McGhee, D. 1998. Looking and acting the part: gays in the armed forces-a case of passing masculinity. Feminist Legal Studies, 4: 205-244.

Muntingh, D.C. 1967. Lesbinisme: 'n Sosiologiese studie. Pretoria: University of Pretoria (Unpublished M.A. thesis).

Patton, M.C. 1978. Utilization-focused evaluation. Beverly Hills, CA: Sage.

Patton, M.C. 1986. Utilization-focused evaluation. $2^{\text {nd }}$ ed. Beverly Hills, CA: Sage.

Patton, M.C. 1990. Qualitative evaluation and research methods. $2^{\text {nd }}$ ed. Newbury Park, CA: Sage.

Patton, M.C. 1997. Utilization-focused evaluation. The new century text. $3^{\text {rd }}$ ed. Thousand Oaks, CA: Sage.

Plummer, K. 1975. Sexual stigma: An interactionist account. London: Routledge \& Kegan Paul Ltd.

Plummer, K. 1981. The making of the modern homosexual. London: Hutchinson \& Co. (Publishers) Ltd.

Plummer, K. 1992. Modern homosexualities: Fragments of lesbian and gay experience. London: Routledge.

Redelinghuys, J.L. 1978. 'n Psigodinamiese ondersoek na die verskynsel van lesbinisme binne $n$ gesinstruktuur. Pretoria: University of Pretoria (Unpublished M.A. thesis). 
Retief, G. 1993. Policing the perverts: An exploratory investigation of the nature and social impact of police action towards gay and bisexual men in South Africa. A research report submitted to the Institute of criminology at the University of Cape Town and to the Centre for Science Development of the Human Sciences Research Council, Pretoria. Research Report 1-93:1-52.

Retief, G. 1994. Keeping sodom out of the laager: state repression of homosexuality in apartheid South Africa. In: Gevisser, M. \& Cameron, E. (Eds.). Defiant Desire: Gay and lesbian lives in South Africa. Braamfontein: Ravan Press. Pp. 99-111.

Richardson, D. \& Seidman, S. (Eds.). Handbook of lesbian and gay studies. Thousand Oaks, CA: Sage.

Schneider, B.E. 1987. Coming out at work: bridging the private/public gap. Work and Occupations, 13 (4): 463-487.

Rimmerman, C. (Ed.). 1996. Gay rights, military wrongs: political perspectives on lesbians and gays in the military. New York: Garland Publishing.

Schurink, W.J. 1981. Gay vroue: 'n Sosiologiese verkenning van die leefwyse van $n$ aantal lesbiers aan die hand van outobiografiese sketse. Pretoria: Human Sciences Research Council.

Schurink, W.J. 1986. Illustration: autobiographical sketch of a lesbian (Lecture 2). In: Ferreira, M. et al. Module 3: Introduction to qualitative research methods. (Lectures presented during the first HSRC School in research methodology, Pretoria, 30 June-10 July.)

Schurink, W.J. 1989. Die realiteit van homoseksualisme: 'n sociologies-kwalitatiewe ontleding. (The reality of homosexualism: a sociological-qualitative analysis.)
Potchefstroom: Potchefstroomse Universiteit vir Christelike Hoër Onderwys. (Unpublished doctoral thesis).

Schurink, W.J. 1999. Programme evaluation: Views and practices from the field and general guidelines for the crime prevention iniatives at the Wynberg, Berea and Marabastad/Belle ombre modal interchanges. (Draft discussion document for the project entitled: Crime Prevention on public transport). Pretoria: HSRC.

Scott, W. \& Stanley, S. 1994. Gays and lesbians in the military. Hawthorne, New York: Aldine de Gruyter.

Simon, W. \& Gagnon, J.H. 1973. A conformity greater than deviance: The lesbian. In: Gagnon, J.H and Simon, W. (Eds.). Sexual Conduct: The social sources of human sexuality. London: Hutchinson.

Stychin, C. 1996. To take him at his word: theorizing law, sexuality and the US military exclusion policy. Social and Legal Studies, 5: 179-200.

Tessina, T.B. 1989. Gay relationships for men and women. Los Angeles: Jeremy P. Tarcher, Inc.

Toms, I.1994. Ivan Toms is a fairy? The South African Defence Force, the End Conscription Campaign, and me. In: Gevisser, M. \& Cameron, E. (Eds.). Defiant Desire: Gay and lesbian lives in South Africa. Braamfontein: Ravan Press. Pp. 258-263.

Weinberg, G. 1973. Society and the healthy homosexual. New York: Anchor Books.

Whisman, V. 1996. Queer by choice: lesbians, gay men and the politics of identity. New York: Routledge.

Wilton, T. 1995. Lesbian studies: setting an agenda. London: Routledge. 